\title{
Influence of Learning Model Using Laboratory and Numeric Ability to Student Learning Result on Thermochemical Material
}

\author{
Gulmah Sugiharti ${ }^{1} \&$ Bastian Jose Wandry Habeahan ${ }^{1}$ \\ ${ }^{1}$ Chemistry Education, State University of Medan, Medan, Indonesia \\ Correspondence: Gulmah Sugiharti, Chemistry Education, State University of Medan, Medan, Indonesia. E-mail: \\ Gulmahsugiharti@yahoo.com
}

Received: January 22, 2018

Accepted: February 24, $2018 \quad$ Online Published: April 27, 2018

doi:10.5539/ies.v11n5p154

URL: https://doi.org/10.5539/ies.v11n5p154

\begin{abstract}
This study aims to determine the influence of learning models and numerical ability of students' chemistry learning outcomes on Thermochemical materials, as well as the interaction between learning models through the use of laboratory and numerical ability. The study was conducted on the students of grade XI IPA SMA N 1 Stabat consisting of 9 classes and 2 classes as samples taken by purposive sampling. Experimental research with factorial $2 \times 2$ factorial ANOVA design. Learning result data obtained from result of thermochemical learning result and student numerical ability data obtained through numerical ability test which have all been validated. The data analysis technique used two way analysis of variance (ANOVA). The result of the research shows that the influence of the learning model using the laboratory on the students' learning outcomes on thermochemical materials with Fcount $>$ Ftable is $4.015>3.99$, there is the effect of high numerical ability and low numerical ability to the chemistry learning result on thermochemical material with Fcount $>$ Ftable value is $23.717>3.99$ and there is interaction between learning model using laboratory with numerical ability to result of thermochemical learning with value Fcount $>$ Ftable that is $11.142>3.99$.
\end{abstract}

Keywords: ANOVA 2x2, learning outcomes, numerical ability, Problem Based Learning Model (PBL)

\section{Introduction}

The main problem in learning in formal education (school) which is still widely found in Indonesia today is about the low learning outcomes of learners. Especially in SMA Negeri 1 Stabat still found the results of student learning is still low. The result of daily test and the average of midterm's examination is still at the value of 68 , far below the value of mastery learning by 75 . Likewise in the learning of chemistry that has not reached the completeness of learning is expected

To improve students' learning outcomes, there is a need for learning that is interesting for students, among others, by using learning and media models in accordance with the material being taught. One of the learning models that can be used on thermochemical materials is a problem-based learning model known as Problem Based Learning (PBL). Thermochemical material is a learning material related to heat related problem (calor) which is close to life. According to Winarno et al. (2018) problem-based learning is learning where students learn about a subject through experience solving problems openly. To improve problem-solving skills, this learning model is considered the most appropriate teaching method. Likewise, according to Hmelo-Silver (2004), Savery (2006) states that PBL is a learning model in which students learn through problem-facilitated problem-solving that focuses on complex issues that have one correct answer. Meanwhile, according to (Becker \& Maunsaiyat, 2004; Blumberg, 2000; Chen et al., 2001) states that Problem-based learning is described as a student-centered, inquiry-based approach and build problem-solving skills. In addition to learning models, effective use of laboratories can also support success in chemistry learning. The use of instructional media, especially the use of laboratory in the teaching and learning process can generate new desires and interests, generate motivation and stimulation of learning activities, and bring psychological influences on students. In learning, there are various learning media that can be used by teachers to attract students' attention in the class, such as: animation, module, concept map, comic, real laboratory, virtual laboratory and others (Arsyad, 2009). The use of laboratory media in this study is distinguished by virtual labs and real laboratories.

Learning media Virtual lab is a computer-based media that contains simulation activities in chemical laboratories and activities indirectly while Real laboratory is learning through direct observation where real learning laboratory 
is equipped with tools and real materials to conduct experiments, in Real lab these students are really confronted with real objects (Kusnadi et al., 2013).

There are various studies that link between the use of Virtual lab and Real labs such as research conducted by Tatli and Ayas (2013), which describes that "Virtual chemistry labs are slightly more effective than Real labs, both of which show the achievement and ability of students to recognize laboratory equipment". Another study was conducted by Aprilia (2015) which states that there is an influence of the PBL learning model using Real media labs and Virtual labs. From mean of cognitive learning achievement of students using learning PBL Virtual laboratories $(71.25 \%)$ better than student using PBL learning with Real lab (58.75\%). In addition, this study was also supported by Kusnadi et al. (2013) which showed a difference in the learning outcomes of chemistry by using a virtual laboratory (73.9\%) slightly higher than that of Real lab (70.8\%). Sugiharti, and SK Hasibuan, 2017) show that there is influence of inquiry learning model by using real laboratory and virtual laboratory on students' chemical learning result on reaction rate material with $\mathrm{F}$ count $>\mathrm{F}$ table i.e. 28.6367 $>3.99$

Chemistry is one of the subjects given in SMA/MA. Chemistry studies mostly contain abstract concepts and are memorative, calculating, thus requiring a good understanding of the concepts (Aprialisa \& Mahdian, 2010). Thermochemical material other than related to life also uses a lot of calculation concepts so that students are expected to better use numerical skills in thermochemical learning. Numerical ability is a special ability in counting, so that numerical ability affects the ability of students to understand and solve the problem of calculation. However, the numerical ability of students is different. There are students who have high numerical ability and low. Students who have high numerical ability will work better in numeracy while students with low numerical skills will have difficulty in counting (Cahyono et al., 2016). Numerical ability is intended to make numerical operation speed accuracy (Addition, Reduction, Multiplication and Division). Numerical abilities in this case include: numerical justification, numerical logic, numerical computation, numerical estimation, and data representation (Abed et al., 2016). Irawan and Kencanawaty (2016) mentioned that numerical ability is the ability possessed by a person to use numbers to calculate and change the problem of story description into figures which can then be calculated.

Research by Fatoke et al. (2013) shows that learning problem solving and numerical ability of students can improve chemical performance. So it is recommended that teachers should consider the numerical ability of students in the teaching-learning process to effectively deliver their lessons in order to improve students' performance in chemistry. The result of numerical ability study has also been done by Ayodele (2014) that numerical ability of students is one of the predictors in chemistry learning where teacher instructional, time and numerical ability of students when calculated accounted for $63.9 \%$ of total variance $(R=0.639, p<0.05)$.

\section{Methodology}

\subsection{Design of the study}

This study aims to determine the influence of learning models and numerical ability of students' chemistry learning outcomes on Thermochemical materials, as well as the interaction between learning models through the use of laboratory and numerical ability.

\subsection{Participants}

The population in this study were all student of class XI IPA at SMAN 1 Stabat curriculum of 2013, with the number of 9 class with the number of 35 student per class.

The sampling technique is done two times, namely taking a sample class and student sample, the sampling classes are conducted with purposive sampling technique, and so did the sampling of students in class were also conduted with purposive sampling technique, and so did the sampling students in class were also conducted with a purposive sampling based on the value of pretest relatively homogengeous and also based test against numeric abilities of student, to measure the level of numerical ability of students so that each class is divided into two parts which have a high numerical ability and students who have a low numerical abilities. After the determination of the sample were obtained 2 class. The first sample used as the firs experimental class given PBL learning model using real media, while the second sample used as the experimental class second treated Problem Based Learning model study using virtual media.

\subsection{Measures and Covariates}

This study uses a test instrument. The test instrument is an objective test (multiple choice questions). Instrument test used in this research is test result of student's chemistry learning that is pretest and posttest. Pretest is given to the sample before treatment (treatment) in order to know the homogeneity and normality or similarity characteristic of the student's early ability. Posttest is given after completion of treatment process (treatment) with 
the aim to know student learning outcomes.

\subsection{Research Design}

The research design used is $2 \times 2$ factorial design. There are two factors studied namely PBL learning model using laboratory media (A) and numerical ability factor (B). Factor A there are two levels of learning model using virtual media collaboration and real laboratory. For factor B there are two levels of high and low numerical ability.

Table 1. Factorial design of research $2 \times 2$

\begin{tabular}{lcc}
\hline \multirow{3}{*}{ Numerical Ability $(B)$} & \multicolumn{2}{c}{ Learning Model } \\
\cline { 2 - 3 } & \multicolumn{2}{c}{ Problem Based Learning $(\mathrm{A})$} \\
\cline { 2 - 3 } & PBL Virtual Lab $\left(\mathrm{A}_{1}\right)$ & PBL Real Lab $\left(\mathrm{A}_{2}\right)$ \\
\hline High $\left(\mathrm{B}_{1}\right)$ & $\mathrm{A}_{1} \mathrm{~B}_{1}$ & $\mathrm{~A}_{2} \mathrm{~B}_{1}$ \\
Low $\left(\mathrm{B}_{2}\right)$ & $\mathrm{A}_{1} \mathrm{~B}_{2}$ & $\mathrm{~A}_{2} \mathrm{~B}_{2}$ \\
\hline
\end{tabular}

Description:

$\mathrm{A}_{1} \mathrm{~B}_{1}=$ Combination treatment of Problem Based Learning model with virtual media and numerical ability of high students.

$\mathrm{A}_{1} \mathrm{~B}_{2}=$ Combination treatment of Problem Based Learning model with virtual media and low student numerical ability.

$\mathrm{A}_{2} \mathrm{~B}_{1}=$ Combination treatment of Problem Based Learning model with real media and high student numerical ability.

$\mathrm{A}_{2} \mathrm{~B}_{2}=$ Combination treatment of Problem Based Learning model with real media and low student numerical ability.

\section{Results}

Data collected in this study include: numerical ability data and students' chemical learning outcomes. These numerical data capabilities are grouped into two categories: high numerical ability for students with numerical ability scores $\geq$ average numerical score of all students. Low numerical ability categories for students with numerical ability scores $\leq$ average numerical score of all students. Overall data of high and low numerical ability is shown in Table 2.

Table 2. Data distribution of high and low numerical capabilities

\begin{tabular}{cccc}
\hline Numerical Ability & Total & Experiment Class I & Experiment Class II \\
\hline High & 31 & 16 & Frequency \\
Low & 39 & 19 & 15 \\
Total & 70 & 35 & 20 \\
\hline
\end{tabular}

From the data processing presented obtained that for students who are taught by PBL learning model using Virtual Lab media and high numerical ability obtained average learning outcomes $(84.43 \pm 2.80)$, for class which is taught by PBL learning model using Virtual Lab media and low numerical ability obtained by average learning outcomes (73.73 \pm 5.26 ). For classes taught by PBL model using Real Lab media and high numerical ability obtained average learning outcomes $(83.73 \pm 4.06)$ For classes taught by PBL model using Real Lab and low numerical ability obtained average learning outcomes $(74.15 \pm 1.38)$. The average details of the chemistry learning results obtained by the students for each treatment combination are presented in Table 3 . 
Table 3. Meaning of student chemical learning outcomes combined treatment of learning models and numerical thinking abilities

\begin{tabular}{ccc}
\hline \multirow{2}{*}{ Numerical Ability (B) } & \multicolumn{2}{c}{ Learning Models Using Laboratory Media (A) } \\
& PBL Virtual Lab $\left(\mathrm{A}_{1}\right)$ & PBL Real Lab $\left(\mathrm{A}_{2}\right)$ \\
\hline High $\left(\mathrm{B}_{1}\right)$ & $(84.43 \pm 2.80)$ & $(83.73 \pm 4.06)$ \\
Low $\left(\mathrm{B}_{2}\right)$ & $(73.73 \pm 5.26)$ & $(74.15 \pm 1.38)$ \\
\hline
\end{tabular}

Hypothesis testing is done by Analysis of Varians (ANOVA) 2 lane at $\alpha=0,05$ with criterion if Fcount $>$ Ftable then Ho rejected. Based on hypothesis test of data of student learning result, it is concluded that there is interaction between numerical ability (B) with learning model by using laboratory media (A) on thermochemical learning result. A list of learning results that were given a combination of treatment of learning models using laboratory media and numerical abilities is shown in Table 4.

Table 4. ANOVA list of chemical values of students given a combination of learning model treatment using laboratory media and numerical ability

\begin{tabular}{cccccc}
\hline Source of Diversity & $\mathrm{Df}$ & $\mathrm{SSW}$ & $\mathrm{MS}$ & $\mathrm{F}_{\text {count }}$ & $\mathrm{F}_{\text {table }}$ \\
\hline Factor A & 1 & 34.30 & 34.30 & 4.015 & 3.99 \\
Factor B & 1 & 202.62 & 202.62 & 23.717 & 3.99 \\
Interaction AB & 1 & 95.19 & 95.19 & 11.142 & 3.99 \\
Error & 66 & 563.87 & 8.54 & - & - \\
Total & 69 & 895.98 & - & - & - \\
\hline
\end{tabular}

Note. $\mathrm{Df}=$ degree of freedom; $\mathrm{SSW}=$ sum of square, $\mathrm{MS}=$ mean squares.

\section{Discussion}

Hypothesis 1

$\mathrm{F}$ count $(\mathrm{A})>\mathrm{F}(0.05)(1 ; 66)$ where $4.015>3.99$ then Ho1 is rejected, there is influence of learning model of PBL by using media to student learning result on thermochemical material. This influence shows that the class that is learned by PBL learning model using virtual lab media has higher average learning result score that is 84.43 compared to learning model using real lab that is 83.73. Sahyar et al.'s (2017) study found that Problem Solving Ability Students who learned to use Problem-Based Learning Models were better than conventional learning. The results (Gulmah S, 2017) found that PBL models gave better learning outcomes $(26.57 \pm 5.81)$ than Direct Instruction model $(24.04 \pm 2.86)$ and this study concludes that students with high mathematical ability are very suitable to be taught with PBL model. Furthermore, Sugiharti and Hasibuan (2017) study found that there is influence of learning model by using real laboratory and virtual laboratory on students' chemistry learning on reaction rate material with $\mathrm{F}_{\text {count }}>\mathrm{F}_{\text {table }}$ value $\mathrm{F} 28.6367>3.99$. While research Kusnadi et al. (2013) states that learning using virtual lab media more effectively indicated by the average score of cognitive students of 73.9 compared with the average cognitive value of students using real lab of 70.8. Furthermore, according to Tatli et al. (2013) states that some researchers argue that experimenting with virtual labs is more effective than doing real laboratory experiments.

Hypothesis 2

$\mathrm{F}(\mathrm{B})>\mathrm{F}(0.05)(1: 66)$ where $23.717>3.99$ then Ho2 is rejected, meaning there is influence of high numerical ability and low numerical ability to student learning outcomes on thermochemical material. Data on student learning outcomes on thermochemical materials concluded that students who have high numerical ability to provide higher average learning outcomes compared with students who have low numerical ability. The average of student learning outcomes with high numerical ability is 78.62 while the average of student learning outcomes with low numerical ability is 78.20. Abed's (2016) study states that numerical ability tests for students in education can be used to categorize students in the dimensions tested. Research conducted by Olatoye and Aderogba (2011), states that numerical ability affects student achievement in general ability test this is indicated by the percentage value of numerical ability of 35.6\%. In line with this, research conducted by Cahyono et al. (2016) which states that there is a significant relationship between numerical ability with learning achievement on hydrolysis material, from the test t-two parties obtained the value of significance 0.014 and Pearson correlation coefficient 0.304 . While Badru's (2016) study found a high numerical ability to have a higher adjusted average value than those with 
low numerical ability. It is also said that students with high numerical ability perform better than students with low numerical skills.

\section{Hypothesis 3}

F-Count $(\mathrm{AB})>\mathrm{F}(0.05)(1: 66)$ i.e. $11.142>3.99$ then Ho3 is rejected means there is interaction between learning model using laboratory media with numerical ability to student learning result on thermochemical material. In this study, it was found that if the factor of learning model by using laboratory media (factor A) and numerical ability (factor B) is combined, the interaction between the two factors significantly influences student learning outcomes. The form of factor model interaction using medial collaborator (factor A) and numerical ability (factor B) on student learning outcomes can be described as shown in Figure 1.

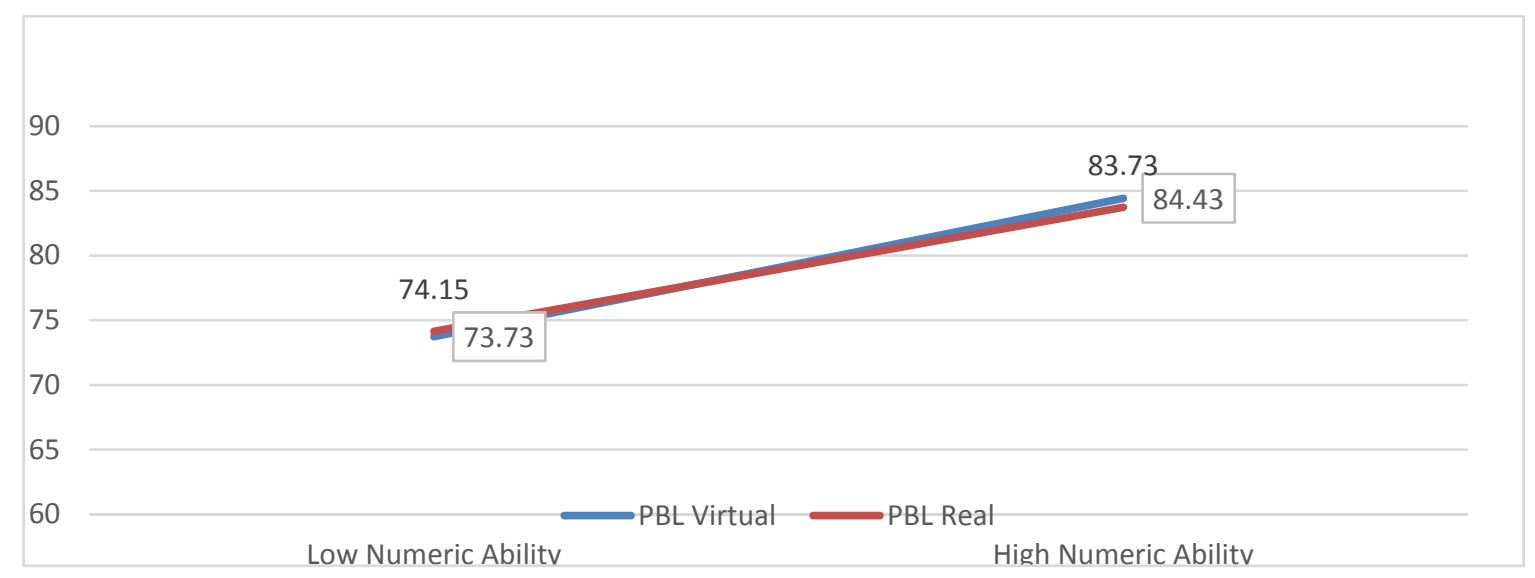

Figure 1. Interaction form factor model learning and numerical ability to student chemistry learning results

Based on the form of interaction between the learning model using laboratory media (factor A) and numerical ability (factor B) on thermochemical learning result as presented in Figure 1. It can be concluded that the student learning outcomes are taught by PBL learning model using virtual lab media with high numerical ability has a higher average learning outcome of 84.43 , while the learning outcomes of students who are studied with PBL learning models using real laboratory media with high numerical ability have a lower average learning outcome of 83.73. Furthermore, the learning outcomes of students who are taught by PBL learning models using virtual lab media with low numerical ability have average learning outcomes of 74.15 , whereas student learning outcomes that are taught by PBL learning models using real laboratory media with low numerical ability have average learning outcome of 73.73. So it can be concluded that there is interaction between learning model using medial collaborator and numerical ability where obtained Fcount for interaction between learning model and numerical

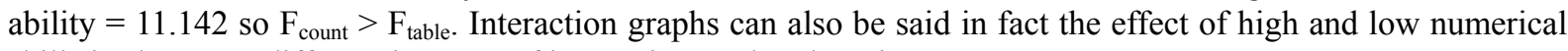
skills is almost no different in terms of improving student learning outcomes.

The interaction between the PBL model and the numerical capability obtained is not as expected, with the intersection of graphic almost coincidental. This occurs because the mean difference between the two treatments is not much different.

\section{Conclusion}

The influence of the learning model using the laboratory on the students' learning outcomes on thermochemical materials with $\mathrm{F}_{\text {count }}>\mathrm{F}_{\text {table }}$ is $4.015>3.99$, there is the effect of high numerical ability and low numerical ability to the chemistry learning result on thermochemical material with Fcount $>$ Ftable value is $23.717>3.99$ and there is interaction between learning model using laboratory with numerical ability to result of thermochemical learning with value Fcount $>$ Ftable that is $11.142>3.99$.

\section{References}

Abed, E. R., Mustafa, M., \& Shindi, Y. A. A. (2016). Developing a Numerical Ability Test for Students of Education in Jordan: An Application of Item Response Theory. International Education Studies, 9(1), 161. https://doi.org/10.5539/ies.v9n1p161

Aprilia, S. (2015). Pembelajaraan Kimia Berbasis Masalah (Problem Based Learning) Dengan Menggunakan 
Laboratorium Real dan Vitual Ditinjau Dari Kemampuan Matematik dan Gaya Belajar Siswa di SMA Negeri 1 Bajo Tahun Pelajaran 2010/2011. Jurnal Propesi Pendidik, 2.

Ayodelle, O. D. (2014). Teacher Instructional Time, Student-Engaged Time and Numerical Ability as Predictors of Student Achievement in Senior Secondary School Chemistry. Journal of Emerging Trends in Educational Research an Policy Studies (JETERAPS), 5(3), 377-380.

Badru, A. K. (2016). Problem-Based Instructional Strategy and Numerical Ability as Determinants of Senior Secondary Achievement in Mathematics. Journal of Education and Practice, 7(13), 89-95. Retrieved from http://iiste.org/Journals/index.php/JEP/article/view/30626/31465

Beker, K. H., \& Maunsaiyat, S. (2004). A comparison of students: Achievement and attitudes between constructivist and traditional classroom environment in Thailand vocational electronics programs. Journal of Vocational Education Research, 29(2), 133-153. https://doi.org/10.5328/JVER29.2.133

Blumberg, P. (2000). Evaluating the evidence that Problem-Based learners are self-directed learners: A review of the literature. In D. H. Evensen, \& E. E. Hmelo (Eds.), Problem-Based Learning: A research perspective on learning interactions (pp. 199-226). Mahwah, NJ: Erlbaum.

Cahyono, D. T., Masykuri, \& Ashadi. (2016). Kontribusi Kemampuan Numerik Dan Kreativitas Terhadap Prestasi Belajar Siswa Pada Materi Pokok Hidrolisis Kelas Xi Mia1 Dan Xi Mia5 Sma Negeri 2 Karanganyar Tahun Pelajaran 2015/2016. Jurnal Pendidikan Kimia (JPK), 5(2). Retrieved from http://jurnal.fkip.uns.ac.id/index.php/kimia

Chen, S. K., Chang, H. F., \& Chiang, C. P. (2001). Group learning factors in a Problem-Based course in oral radiology. Dento Maxillo Facial Radiology, 30(2), 84-87.

Fatoke, A. O., Ogunlade, T. O., \& Ibidiran, V. O. (2013). The Effect of Problem-Solving Instructional Strategy and Numerical Ability on Students' Learning Outcomes. The International Journal of Engineering and Science (IJES), 2(10), 97-102.

Sugiharti, G., \& Hasibuan, S. K. (2017). The Effect of Inquiry Learning Method by Using Laboratory and Logical Thinking on Learning Outcome in Chemical Reaction RateJurnal Pendidikan Kimia (JPKim), 9(1), 229-235. https://doi.org/10.24114/jpkim.v9i1.6184.

Gulmah, S. (2017). The Effect of Learning Model and Mathematical Ability into Student's Learning Outcomes in Evaluation Course of Chemistry Education State University of Medan. Procceding of The 2nd Annual Internatioanal Seminar on Transformative Education and Educational Leadership (AISTEEL) 2017. Grand Mercure Hotel, October 16-17, 2017. https://doi.org/10.2991/aisteel-17.2017.61

Hmelo-Silver, C. E. (2004). Problem-based learning: What and how do students learn? Educational Psychology Review, 16(3), 235-266. https://doi.org/10.1023/B:EDPR.0000034022.16470.f3

Kencanawaty, G., \& Irawan, A. (2016). Peranan Kemampuan Verbal Dan Kemampuan Numerik Terhadap Kemampuan Berpikir Kritis Matematika, Jurnal Pendidikan Matematika FKIP Univ. Muhammadiyah Metro, 5(2), 110-119. https://doi.org/10.24127/ajpm.v5i2.669

Kusnadi. (2013), Pembelajaran Kimia dengan Problem Based Learning Menggunakan Laboratorium Real dan Virtual Ditinjau dari Kemampuan Matematika dan Kemampuan Berpikir Abstrak Siswa. Jurnal Inkuiri, 2(2), 163-172. Retrieved from http://jurnal.fkip.uns.ac.id/index.php/sains

Olatoye, R. A., \& Aderogba, A. A. (2011). Performance of Senior Secondary School Science Students in Aptitude Test: The Role of Student Verbal and Numerical Abilities. Journal of Emerging Trends in Educational Research and Policy Studies (JETERAPS) Nigeria, 2(6), 431-435. Retrieved from http://www.uniosun.edu.ng/jdownloads/Journals\%20and\%20Publications/Publications/Education/performa nce_of_senior_secondary_school_science_students_in_aptitude_test_-_the_role_of_student_verbal_and_nu merical_abilities-dr.a.a_aderogba.pdf

Pratiwi, Y., \& Redjeki, M. (2014). Pelaksanaan Model Pembelajaran Learning (PBL) Pada Materi Redoks Kelas X SMA Negeri 5 Surakarta Tahun Pelajaran 2013/2014. Jurnal Pendidikan Kimia (JPK), 3(3). Retrieved from http://jurnal.fkip.uns.ac.id/index/php/kimia

Sahyar, Ridwan, \& Tiorna. (2017). The Effect of Problem Based Learning (PBL) Model and Self Regulated Learning (SRL) toward Physics Problem Solving Ability (PSA) of Students at Senior High School. American Journal of Educational Research, 5(3), 279-283. Retrieved from http://www.uniosun.edu.ng/jdownloads/Journals\%20and\%20Publications/Publications/Education/performa 
nce_of_senior_secondary_school_science_students_in_aptitude_test_-_the_role_of_student_verbal_and_nu merical_abilities-dr.a.a_aderogba.pdf

Savery, J. R. (2006). Overview of Problem-based Learning: Definitions and Distinctions. Interdisciplinary Journal of Problem-Based Learning, 1(1). https://doi.org/10.7771/1541-5015.1002

Tatli, Z., \& Ayas, A. (2013). Effect of a Virtual Chemistry Laboratory on Students' Achievement. Educational Technology \& Society, 16(1), 159-170. http://www.ifets.info.

Winarno, S., Muthu, K. S., \& Ling, L. S. (2018). Direct Problem-Based Learning (DPBL): A Framework for Integrating Direct Instruction and Problem-Based Learning Approach. International Education Studies, 11(1), 119. https://doi.org/10.5539/ies.v11n1p119

\section{Copyrights}

Copyright for this article is retained by the author(s), with first publication rights granted to the journal.

This is an open-access article distributed under the terms and conditions of the Creative Commons Attribution license (http://creativecommons.org/licenses/by/4.0/). 